\title{
STRATEGI MANAJEMEN SEKOLAH DASAR DALAM MENUMBUHKAN JIWA KEWIRAUSAHAAN
}

\author{
Adevia Indah Kusuma
}

STKIP Muhammadiyah Bangka Belitung adevia.indah@gmail.com

\begin{tabular}{ll}
\hline Informasi artikel & \\
Sejarah artikel & \\
Diterima & $: 5 /$ I0 \\
Revisi & $:$ I5 \\
Dipublikasikan & $: 28 / 12 / 2107$
\end{tabular}

\section{Kata kunci:}

strategi,

manajemen sekolah dasar,

kewirausahaan

\section{Keyword:}

strategy,

primary school management,

entrepreneurship \begin{abstract}
ABSTRAK
Semangat dan jiwa kewirausahaan muncul melalui sebuah proses yang panjang, terutama bagi mereka yang tidak memiliki pengalaman atau tidak terbiasa berada di lingkungan yang menunjang tumbuhnya semangat dan jiwa kewirausahaan tersebut. Seringkali lembaga pendidikan hanya menghasilkan peserta didik yang terampil namun tidak memiliki jiwa kewirausahaan, sehingga pada akhirnya peserta didik terbentuk sebagai tenaga siap bekerja bukan pencipta lapangan pekerjaan. Jauh sebelumnya, pada proses penanaman jiwa kewirausahaan melalui pendidikan, terdapat proses pembentukan jiwa kewirausahaan yaitu melalui proses pembelajaran dan pembiasaan diri sebagai pencetus karakter di kemudian hari. Dalam hal ini, Sekolah Dasar (SD) sebagai pintu wajib belajar pendidikan pertama bagi anak tentunya memiliki peranan yang penting. Secara eksplisit, di jenjang pendidikan SD tidak ada kewajiban untuk mempelajari kewirausahaan. Namun, jika dihubungkan dengan kebutuhan, harapan dan dukungan pemerintah terhadap tumbuhnya jiwa kewirausahaan melalui pendidikan, maka hal ini layaknya perlu mendapatkan perhatian lebih. Berikut dijabarkan beberapa strategi yang dapat dilakukan manajemen dalam upaya menumbuhkan jiwa kewirausahaan di lingkungan SD yaitu melalui kegiatan market week, kegiatan field trip pasar tradisional dan pasar modern, ekskul berbasis kewirausahaan, pengembangan perangkat pembelajaran, pengadaan lab kewirausahaan, penataan suasana sekolah untuk penanaman nilai-nilai kewirausahaan, pelatihan berbasis kewirausahaan yang berkesinambungan bagi tenaga pendidik, dan pemberian penghargaan.
\end{abstract}

\section{Pendahuluan}

Menurut teori, kebutuhan suatu negara untuk disebut sebagai negara maju di antaranya adalah memiliki minimal 2\% wirausaha dari total jumlah penduduknya. Menkop Puspayoga menjelaskan (daring 2017, http://www.depkop.go.id) berdasarkan data BPS 2016 dengan jumlah penduduk 252 juta, jumlah wirausaha non pertanian yang menetap mencapai 7,8 juta orang atau 3,I persen. Dengan demikian 
tingkat kewirausahaan Indonesia telah melampaui 2 persen dari populasi penduduk, sebagai syarat minimal suatu masyarakat akan sejahtera. Menkop mengakui, ratio wirausaha sebesar 3, I persen itu masih lebih rendah dibandingkan dengan negara lain seperti Malaysia 5 persen, China IO persen, Singapura 7 persen, Jepang II persen maupun AS yang 12 persen. "Namun setidaknya sudah di atas batas minimal 2 persen dan itu akan terus berkembang," katanya. Lebih jauh beliau mengatakan, bertumbuhnya wirausaha tak lepas dari peran masyarakat bersama pemerintah yang terus mendorong, juga swasta dan kalangan mahasiswa atau kampus.

Gerakan Kewirausahaan Nasional (GKN) telah dilakukan pemerintah sejak tahun 20II, dan pada tahun 2017 ini mengangkat tema wirausaha tangguh, inovatif dan peduli. Dalam rentang waktu tersebut (20II-2017), pemerintah melalui berbagai kegiatan terus mendorong penggalakan kewirausahaan di masyarakat. Di bidang pendidikan sebenarnya justru telah terlebih dahulu dilakukan pemerintah melalui berbagai program yang bertujuan untuk menumbuhkan semangat kewirausahaan di kalangan mahasiswa.

Melalui pendidikan yaitu ristekdikti (20I7: I), pemerintah telah meluncurkan berbagai program kewirausahaan. Pada tahun 1998 dikembangngkan Program Kreativitas Mahasiswa Kewirausahaan (PKMK) dan Cooperative Educatin Program (Co-Op) di industri. Kemudian, pada tahun 2003 dikembangkan program Cooperative Education Program (Co-Op) di UMKM, yang memberikan kesempatan belajar berwirausaha bagi mahasiswa di UMKM. Sedangkan pada tahun 2009 dikembangkan Program Mahasiswa Wirausaha (PMW) berupa pembinaan dan pemberian modal bagi mahasiswa yang ingin berwirausaha. Pada tahun 20I4, Direktorat Jendral Pendidikan Tinggi meluncurkan program Expo Kewirausahaan Mahasiswa (KMI Expo) yang merupakan perluasan dari program sejenis Expo Kweirausahaan mahasiswa yang sebelumnya dilaksanakan di tingkat politeknik. Pada tahun 2016 ini dilakukan revitalisasi dan integrasi program pembinaan kewirausahaan menjadi Program Kewirausahaan Mahasiswa Indonesia (PKMI), yang secara umum memiliki tiga tujuan utama, yaitu:

I. Membentuk karakter wirausaha mahasiswa berupa proses pengintegrasian antara hardskill dan softskill (knowledge, skill, personal quality: motivation, attitude, behaviour, traits, values) sehingga terbentuk kapasitas wirausaha.

2. Mendorong tumbuhnya wirausaha muda berbasis keilmuan.

3. Mendorong pembentukan dan penguatan kelembagaan pengembangan kewirausahaan di perguruan tinggi.

PKMI ini memberikan kesempatan kepada mahasiswa untuk memunculkan ide dan kreativitasnya dalam menciptakan produk/jasa. Penelitian tersebut kemudian ditindaklanjuti dengan pengadaan program kreativitas mahasiswa lainnya yang lebih mendalam sehingga ide dan kreativitas tersebut dapat diwujudkan sekaligus bersinergi dengan kampus dan masyarakat usaha.

Dukungan pemerintah tersebut membuktikan keseriusan pemerintah dalam mensukseskan tumbuhnya wirausaha ini khususnya melalui pendidikan. Kegiatan pendidikan diharapkan bersinergi dengan proses penanaman jiwa kewirausahaan sehingga harapannya bahwa mahasiswa setelah lulus memiliki keinginan untuk berwirausaha. Berdasarkan data BPS (daring http://bps.go.id) tingkat pengangguran terbuka di Indonesia tahun 2017 mencapai 5,33 persen. Dengan adanya pembinaan kewirausahaan yang lebih giat di kalangan mahasiswa diharapkan dapat mengubah pola pikir lulusan perguruan tinggi dari pencari kerja (job seeker) menjadi pencipta lapangan pekerjaan (job creator).

Agar usaha pemerintah dapat terlaksana dengan baik dalam menumbuhkan jiwa kewirausahaan di kalangan mahasiswa, maka perlunya memiliki banyak tenaga pendidik yang juga berjiwa kewirausahaan. Kendalanya adalah masih banyak tenaga pendidik yang belum berjiwa kewirausahaan, sehingga kewirausahaan pada akhirnnya tersampaikan hanya sebatas pengetahuan (teori) saja. Pada jenjang sekolah atas, menengah dan dasar juga masih banyak ditemui guru yang kurang memanfaatkan fasilitas 
media pembelajaran, padahal melalui pemanfaatan media pembelajaran dapat memberikan efek positif bagi siswa untuk merangsang kemampuan soft skills yang berguna bagi pembentuk jiwa kewirausahaannya seperti untuk berfikir kritis dan kreatif.

Menurut Susilana (2009: 9), secara umum media mempunyai kegunaan:

I. Memperjelas pesan agar tidak terlalu verbalistis.

2. Mengatasi keterbatasan ruang, waktu, tenaga dan daya indera.

3. Menimbulkan gairah belajar, interaksi lebih langsung antara murid dengan sumber belajar.

4. Memungkinkan anak belajar mandiri sesuai dengan bakat dan kemampuan visual, auditori, dan kinestetiknya.

5. Memberikan rangsangan yang sama, mempersamakan pengalaman dan menimbulkan persepsi yang sama.

Selain itu (masih dalam buku yang sama), kontribusi media pembelajaran menurut Kemp and Dayton, 1985:

I. Penyampaian pesan pembelajaran dapat lebih terstandar.

2. Pembelajaran dapat lebih menarik.

3. Pembelajaran menjadi lebih interaktif dengan menerapkan teori belajar.

4. Waktu pelaksanaan pembelajaran dapat diperpendek.

5. Kualitas pembelajaran dapat ditingkatkan.

6. Proses pembelajaran dapat berlangsung kapanpun dan di manapun diperlukan.

7. Sikap positif siswa terhadap materi pembelajaran serta proses pembelajaran dapat ditingkatkan.

8. Peran guru berubah ke arah yang positif.

Semangat dan jiwa kewirausahaan tidak akan muncul tiba-tiba tetapi melalui sebuah proses yang panjang, terutama bagi mereka yang tidak memiliki pengalaman atau tidak terbiasa berada di lingkungan yang menunjang tumbuhnya semangat dan jiwa kewirausahaan tersebut. Semakin dini semangat dan jiwa kewirausahaan ditanamkan maka semakin besar kemungkinan munculnya mahasiswa yang berjiwa kewirausahaan melalui pendidikan ini. Karena sampai saat ini seringkali lembaga pendidikan hanya menghasilkan peserta didik yang terampil namun tidak memiliki jiwa kewirausahaan, sehingga pada akhirnya peserta didik terbentuk sebagai tenaga siap bekerja bukan pencipta lapangan pekerjaan.

Senada dengan pendapat tersebut, Kasmir (2016:4) menyebutkan bahwa kita perlu prihatin dengan rendahnya minat wirausaha di kalangan mahasiswa dan pemuda. Namun, kita tidak perlu menyalahkan siapa pun, yang jelas kesalahan ada pada kita semua. Sekarang inilah kesempatan kita untuk mendorong para pelajar dan mahasiswa untuk mulai mengenali dan membuka usaha atau berwirausaha. Pola pikir dan lingkungan yang selalu berorientasi menjadi karyawan mulai sekarang kita putar balik menjadi berorientasi untuk mencari karyawan (pengusaha).

Jauh sebelumnya, dalam proses penanaman jiwa kewirausahaan melalui pendidikan, terdapat proses pembentukan jiwa kewirausahaan yaitu melalui proses pembelajaran dan pembiasaan diri sebagai pencetus karakter di kemudian hari. Dalam hal ini, maka Sekolah Dasar (SD) sebagai pintu wajib belajar pendidikan pertama bagi anak tentunya memiliki peranan yang penting. Secara eksplisit, pada jenjang pendidikan Sekolah Dasar tidak terdapat kewajiban untuk mempelajari kewirausahaan. Akan tetapi, jika dihubungkan dengan kebutuhan, harapan dan dukungan pemerintah terhadap tumbuhnya jiwa kewirausahaan melalui pendidikan, maka hal ini layaknya perlu mendapatkan perhatian lebih. 
Dari jabaran di atas, dapat diketahui beberapa fakta berikut yang berkaitan dengan proses menumbuhkan semangat dan jiwa kewirausahaan melalui pendidikan, yaitu:

I. Masih tingginya jumlah pengangguran terdidik.

2. Sekolah Dasar merupakan pintu pertama bagi pendidikan karakter kewirausahaan.

3. Kurangnya pemanfaatan fasilitas untuk menunjang tumbuhnya kewirausahaan di sekolah.

4. Masih banyak tenaga pendidik yang belum berjiwa kewirausahaan.

Hal ini menimbulkan pertanyaan lebih lanjut, yaitu strategi manajemen Sekolah Dasar apa saja yang bisa dilakukan untuk menumbuhkan jiwa kewirausahaan?

Solusi untuk mengatasi permasalahan ini meliputi dua besaran, yaitu:

I. Bagaimana mempersiapkan tenaga terdidik yang berjiwa kewirausahaan?, dan

2. Bagaimana memiliki tenaga pendidik yang berjiwa kewirausahaan?

\section{Metode Penelitian}

Metode yang digunakan dalam menyusun gagasan ini adalah teknik dalam melakukan kajian literatur. Menurut Setyono dalam teaching resource (http://eprints.dinus.ac.id) literature review berisi ulasan, rangkuman dan pemikiran penulis tentang beberapa sumber pustaka tentang topik yang dibahas. Lebih lanjut disebutkan langkah-langkah dari literature reviews yaitu formulasi permasalahan, cari literature, evaluasi data, analisis dan interpretasikan. Sedangkan cara melakukan literature review dengan mencari kesamaan (compare), mencari ketidaksamaan (contrast), memberikan pandangan (criticize), membandingkan (synthesize), meringkas (summarize).

Adapun variabel yang dikaji adalah cara untuk mempersiapkan tenaga terdidik dan pendidik yang berjiwa kewirausahaan sehingga nantinya dapat dijadikan strategi bagi manajemen SD dalam menumbuhkan jiwa kewirausahaan di lingkungan SD.

\section{Hasil Penelitian dan Pembahasan}

Menurut Ciputra dalam Rachmadyanti (2016: 430) nilai-nilai kewirausahaan mengandung karakterkarakter baik dalam kehidupan anak. Hal ini sejalan dengan pendapat Wibowo (2010: 22) bahwa pendidikan kewirausahaan seharusya memang dilakukan sejak dini diajarkan di jenjang awal pendidikan yaitu Taman kanak- kanak dan Sekolah Dasar. Tentunya materi yang disampaikan disesuaikan dengan jejang pendidikan dan usia siswa. Jiwa entrepreneurship ini memberikan kontribusi yang positif bagi kehidupan anak. Pendapat Sandiaga Uno dalam Wardhana (2013:14I) menyatakan bahwa kewirausahaan bertujuan untuk menjadikan seseorang menjadi lebih baik, bukan semata- mata membuat seseorang menjadi kaya. Kewirausahaan adalah tentang kerjasama dengan orang lain, karena kewirausahaan juga berbicara tentang bagaimana memberikan manfaat bagi orang lain. Melalui pendidikan kewirausahaan ini diharapkan kelak anak dapat mandiri dan memberikan kesempatan bekerja bagi orang lain.

Jiwa entrepreneurship dapat melatih anak untuk mampu bertindak dan bersikap cerdas dalam menghadapi berbagai tantangan kehidupan. Ciputra (2009: 12) juga menyebutkan bahwa salah satu kategori entrepreneurship adalah academic Entrepreneur, hal ini menggambarkan akademisi yang mengajar atau mengelola lembaga pendidikan dengan pola dan gaya entrepreneur sambil menjaga tujuan mulia pendidikan. Sebagai bentuk academic entrepreneur, dicontohkan oleh kegiatan pendidikan kewirausahaan Sekolah Ciputra, misalnya dengan memberikan tugas kepada siswa sekolah dasar untuk mengamati dan terjun langsung pada kegiatan usaha di sekitar mereka. Para orangtua siswa juga ikut mendukung adanya program dari Sekolah Ciputra tersebut, dan menilai baik untuk mengembangkan potensi anak, yang sebelumnya berpendapat bahwa kewirausahaan ini baru bias diajarkan ketika anak dewasa kelak. Pakar kepribadian dan Presiden Direktur Lembaga Pendidikan Duta Bangsa Mien 
Rachman Uno dalaam Wijatno (2009: I25) menyebutkan bahwa untuk menjadi wirausahawan handal, dibutuhkan karakter seperti kemampuan untuk dapat berkomunikasi, mampu membawa diri di berbagai lingkungan, menghargai waktu (time orientation), empati, mau berbagi dengan orang lain, mampu mengatasi stress, dapat mengendalikan emosi, dan mampu membuat keputusan.

Terdapat beberapa strategi yang dapat dilakukan manajemen Sekolah Dasar (SD) dalam menumbuhkan jiwa kewirausahaan di lingkungannya, yaitu:

I. Mempersiapkan tenaga terdidik yang berjiwa kewirausahaan

a. Melakukan kegiatan Market Week di sekolah

Pada prinsipnya kegiatan ini sama dengan kegiatan market day yang sudah cukup familiar di kalangan jenjang pendidikan SD, di mana siswa berperan aktif dalam persiapan produk, kegiatan dalam berjualan, maupun pelaporan hasil penjualan. Beda gagasan market week adalah bahwa kegiatan berjualan itu dilakukan dalam kurun waktu sepekan dengan mengarahkan kelas 6 pada hari Senin, kelas 5 pada hari Selasa, begitu seterusnya hingga kelas I. Market week akan memberikan nuansa yang berbeda bagi siswa karena dapat benar-benar merasakan kegiatan tersebut hingga sepekan lamanya meskipun hanya berpartisipasi Ihari dalam Ipekan, namun pada hari lainnya mereka dapat melihat dan belajar dari tiap penampilan yang dilakukan oleh kelas lainnya.

Dari kegiatan ini pembentukan karakter jujur, bertanggung jawab, mampu bekerja sama, berani, serta dapat pula dijelaskan implementasinya atas mata pelajaran terkait yang disesuaikan dengan level kelasnya seperti matematika (berhitung laba rugi, membuat laporan), IPS (pengenalan jenis transaksi, penguatan sikap bertanggung jawab, bekerja sama), agama (karakter jujur, berbagi/beramal, pengenalan profesi pedagang dalam pandangan agama, teladan berdagang pada Nabi Muhammad, SAW), bahasa Indonesia (kemampuan berbicara dengan bahasa yang baik) dan sebagainya.

Keberhasilan strategi ini juga bergantung pada kemampuan tenaga pendidik dalam menghubungkan antara teori pada tiap mata pelajaran yang diberikan dengan kegiatan market week yang dilakukan selama sepekan tersebut, sehingga dibutuhkan persamaan persepsi semua tenaga pendidik dalam pekan kegiatan tersebut.

Pada kegiatan ini, wali murid pun bisa diajak pihak sekolah untuk turut berpartisipasi dalam menumbuhkan semangat kewirausahaan dengan mengundang para orangtua/keluarga untuk dapat hadir dalam kegiatan market week serta berpartisipasi dalam kegiatan transaksi jual beli.

Daring (http://sdit-tq.miastasikmalaya.com/) market Day adalah salah satu model pembelajaran yang bertujuan memberikan pemahaman dan kesadaran yang lebih utuh tentang kehidupan, serta menumbuhkan jiwa entrepreneur, memahami dunia bisnis, melatih kreativitas dan inovasi pada siswa. Market Day juga dapat menumbuhkan rasa percaya diri anak, meningkatkan kemampuan komunikasi anak dan melatih kecerdasan bisnis anak. Orang tua dapat memanfaatkan kegiatan Market Dayuntuk menunjukkan dukungannya atas proses pendidikan anak-anaknya, sementara guru dan sekolah dapat memanfaatkan wahana Market Day untuk memperkuat soliditas komunitas sekolah, kegiatan Market Day juga dapat mengajarkan sikap kepedulian dan berbagai kepada anak karena keuntungan yang didapatkan akan dilaurkan untuk kegiatan-kegiatan sosial yang diadakan sekolah setiap tahunnya.

b. Kegiatan Field Trip ke Pasar Tradisional dan Pasar Modern

Field trip atau karyawisata daring (http://kbbi.web.id) adalah kunjungan ke suatu objek dalam rangka memperluas pengetahuan dalam hubungan dengan pekerjaan seseorang atau sekelompok orang. Kegiatan ini akan mendekatkan siswa kepada kegiatan yang lebih nyata terjadi di kehidupan sehari-hari, yaitu melalui field trip ke pasar tradisional dan pasar modern. 
Manfaat dari kegiatan ini, siswa dapat melihat secara langsung dan menghubungkannya dengan teori yang telah dipelajari sebelumnya. Kunjungan ke dua tempat berbeda ini (pasar tradisional dan pasar modern) juga dapat menumbuhkan imajinasi dan kreativitas mereka, misalnya dengan memancing pertanyaan di manakah pemilik sebenarnya dari barang yang dijual di pasar modern?, atau sebutkan hal apa saja yang berbeda antara pasar tradisional dan pasar modern!, dan sebagainya. Materi yang disampaikan atau yang dibahas dapat diesuaikan level kelasnya.

Di antara penelitian mengenai metode field trip (karyawisata) ini sebagai berikut:

Pertama, penelitian oleh Iwin Pakaya berjudul Meningkatkan Kemampuan Siswa Menulis Puisi Melalui Metode Karya Wisata Di Kelas II SDN 02 Bungalo Utara Kabupaten Bone Bolango, memperlihatkan hasil pembelajaran menulis puisi dengan metode karyawisata pada siswa kelas II SDN 02 Bulango Utara Kabupaten Bone Bolango meningkat.

Kedua, penelitian oleh Badi’atul Fitriyah berjudul Peranan Metode Karyawisata (Field-Trip) dalam Meningkatkan Keaktifan Belajar Anak Usia Dini di PAUD Annisa Pekajangan Kedungwuni Pekalongan, dengan hasil peranan karyawisata di PAUD Annisa Pekajangan ialah sebagai hiburan ketika anak mengalami kejenuhan belajar dalam ruang kelas terus menerus. Sehingga dengan adanya metode karyawisata ini anak akan lebih banyak beraktivitas dan mempelajari hal-hal yang belum mereka jumpai. Melalui karyawisata anak usia dini mendapat kesempatan untuk menumbuhkan minat anak kepada sesuatu hal, memperluas perolehan informasi, pengetahuan, memperluas wawasan, meningkatkan kemampuan hidup bermasyarakat, juga memperkaya lingkup progam kegiatan belajar PAUD yang tidak mungkin dihadirkan di dalam kelas.

Ketiga, penelitian Hana Aqmaria Putri dengan judul Efektivitas Metode Karyawisata Untuk Meningkatkan Kemampuan Matematika Penaksiran Harga Barang yang Dibeli Pada Siswa Autis Kelas VIII SMPLB di SLB Citra Mulia Mandiri menunjukkan hasil bahwa intervensi yang dilakukan menggunakan metode karyawisata memiliki efektivitas untuk meningkatkan kemampuan penaksiran harga barang yang dibeli pada anak autis.

Dari beberapa hasil penelitian di atas, optimisme penggunaan metode field trip berbasis kewirausahaan ini juga akan memberikan dampak yang positif bagi siswa Sekolah Dasar yang mengikuti kegiatannya.

\section{c. Pengadaan Ekskul Kewirausahaan}

Ekskul kewirausahaan di SD dapat dilakukan untuk lebih meningkatkan minat siswa. Pada kegiatan ekskul kewirausahaan, kegiatan siswa bisa diisi dengan kegiatan role play, simulasi, observasi lingkungan sekolah dan lain-lain di mana tujuannya adalah untuk melatih daya berimajinasi, mencari jalan keluar dari suatu permasalahan, menumbuhkan motivasi, membangun semangat positif, membudayakan sikap kreatif, disiplin, senang menabung, beramal, sikap peduli dan sebagainya melalui berbagai kegiatan yang dilakukan.

Agar ekskul ini dapat memberikan manfaat yang maksimal pada siswa, maka sangat dibutuhkan kreativitas pembimbing atau pelatih dari kegiatan ekskul kewirausahaan tersebut serta materi pelatihan yang terstruktur agar penyampaian inti dari kegiatan ekskul dapat benar-benar diterapkan oleh siswa dalam kehidupan sehari-hari.

Kemendiknas dalam Hakim (20I2: Vol I No.2) menyebutkan nilai-nilai yang dikembangkan harus diarahkan pada pengembangan nilai-nilai dari ciri-ciri seorang wirausaha. Menurut para ahli kewirausahaan, ada banyak nilai-nilai kewirausahaan yang dianggap paling pokok dan sesuai dengan tingkat perkembangan peserta didik sebanyak I7 (tujuh belas) nilai yang seharusnya dimiliki oleh peserta didik dan warga sekolah yang lain. Implementasi dari nilai-nilai pokok kewirausahaan tersebut tidak secara langsung dilaksanakan sekaligus oleh satuan pendidikan, namun dilakukan secara bertahap. Hal ini bukan berarti membatasi penanaman nilai-nilai (internalisasi) kewirausahaan tersebut kepada semua sekolah secara seragam, namun setiap jenjang satuan pendidikan dapat 
menginternalisasikan nilai-nilai kewirausahaan yang lain secara mandiri sesuai dengan keperluan. Implementasi nilai-nilai kewirausahaan yaitu: mandiri, kreatif, berani mengambil resiko dengan pertimbanganberorientasi pada tindakan, kepemimpinan, kerja keras, Jujur, Disiplin, Inovatif, Tanggung-jawab, Kerja sama, Pantang menyerah (ulet), Komitmen, Realistis, Rasa ingin tahu, Komunikatif, Motivasi kuat untuk sukses (Kemendiknas: 2010, I0).

\section{d. Pengadaan Laboratorium Kewirausahaan}

Laboratorium (lab) kewirausahaan juga dapat menjadi salah satu strategi manajemen SD untuk menumbuhkan jiwa kewirausahaan sejak dini ini. Pada lab tersebut dapat dilengkapi berbagai media yang berkaitan dengan kegiatan kewirausahaan khususnya dalam konsep berjualan. Siswa diarahkan untuk pengenalan dan penggunaan alat-alat seperti alat ukur (berbagai jenis timbangan), alat hitung (contohnya kalkulator, mesin cash register), alat bantu (seperti label harga, kartu stok, etalase), dan pencatatan laporan (barang masuk, barang keluar, laba/rugi). Materi dapat disesuaikan dengan level kelas. Pengadaan jenis barang pun dapat dilakukan secara sederhana misalnya saat ini telah banyak education toys yang fungsinya menyerupai peralatan sebenarnya seperti permainan cash register, shopping trolley, dan lain-lain yang tentunya untuk biaya pengadaan jauh lebih murah dibandingkan barang aslinya. Pengadaan laboratorium kewirausahaan akan memberikan wawasan bagi siswa dalam menunjang proses pembelajaran di kelas serta meningkatkan keterampilan siswa dalam pemanfaatan sumber daya yang berkaitan dengan kegiatan kewirausahaan.

Saat ini lab kewirausahaan telah ada pada jenjang tingkat pendidikan perguruan tinggi contohnya seperti: Lab Kewirausahaan (ADC) milik Universitas Muhammadiyah Sukabumi dan Lab Kewirausahaan Universitas Negeri Yogyakarta.

Lab kewirausahaan hadir dalam pemenuhan kebutuhan praktikum kewirausahaan, hal ini tentunya dapat menjadi contoh bahwa di tingkat pendidikan dasar sekalipun lab berbasis kewirausahaan sudah dapat diadakan.

Dalam Ningsih (prosiding, 20I2) menurut Saragih (2000: 2I) mini lab merupakan model kegiatan praktikum yang dapat dilakukan di dalam kelas. Kegiatan mini lab melibatkan siswa dalam belajar dan metode ilmiah, sehingga dapat digunakan untuk melatih kemampuan berpikir dan membangun konsep-konsep ilmu pengetahuan, selain itu mini lab ini dapat meningkatkan partisipasi siswa dalam pembelajaran, karena siswa terlibat langsung dalam membangun pengetahuannya melalui kegiatan fisik/peragaan. Jadi siswa mempunyai pengalaman sendiri untuk langsung menanamkan ide, konsep, dan keterampilan tersebut di dalam memori jangka panjangnya. Melalui metode inilah kegiatan kewirausahaan dikemas. Hasil penelitian berjudul Penerapan Model Pembelajaran Mini Lab untuk Melatih Dasar-Dasar Entrepreneurship Pada Siswa Menengah Pertama ini menunjukkan hasil bahwa kegiatan tersebut membuat siswa lebih aktif dan tidak pasif, hasil belajar pun menunjukkan ketuntasan klasikal kelas yang meningkat.

Dapat disimpulkan bahwa keberadaan lab kewirausahaan akan lebih memaksimalkan keterampilan siswa dan mempercepat proses penanaman jiwa kewirausahaan siswa.

e. Penataan Suasana Sekolah Berbasis Kewirausahaan

Penanaman nilai-nilai kewirausahaan juga dapat dilakukan manajemen sekolah denganmelakukan penataan suasana sekolah yang berjiwa kewirausahaan. Sebagai contoh terdapat hiasan kata-kata motivasi yang tergantung di setiap sudut sekolah, keteladanan Nabi Muhammad, SAW yang bergelar Al-Amin dalam berdagang, kisah sukses pengusaha muda, dan sebagainya.

\section{f. Penghargaan}

Pemberian penghargaan unuk merangsang tumbuhnya jiwa kewirausahaan pun merupakan satu langkah yang tidak kalah pentingnya. Bagi siswa yang berprestasi, dukungan penghargaan pihak 
sekolah dapat dilakukan dengan cara pemberian ijin dispensasi mengikuti kegiatan, sertifikat, dukungan fasilitas yang dibutuhkan, hadiah (barang/uang saku), dan sebagainya.

2. Memiliki Tenaga Pendidik yang Berjiwa Kewirausahaan

a. Mengembangkan Perangkat Pembelajaran

Tenaga pendidik didorong untuk terus melengkapi dan mengembangkan perangkat pembelajaran yang telah disesuaikan dengan penanaman jiwa kewirausahaan untuk siswa. Penyesuaian perangkat pembelajaran ini akan membantu tenaga pendidik lebih terarah untuk mencapai tujuan yang diharapkan. Dalam Kurtilas maupun KTSP, perangkat pembelajaran masih memberikan kesempatan yang seluasnya bagi tenaga pendidik untuk secara kreatif mengembangkan materi yang ada.

Menurut Budiawan (20II: I8), untuk mengembangkan jiwa dan sikap kewirausahaan pada siswa, sekolah hendaknya membenahi komponen-komponen dan perangkat-perangkat pembelajaran kewirausahaan. Di antara beberapa komponen-komponen dan perangkat-perangkat pembelajaran kewirausahaan tersebut adalah pembenahan kurikulum pendidikan kewirausahaan. Menurut Soemanto (1989: I46) dalam usaha mewujudkan manusia wiraswasta di lingkungan sekolah, tidak perlu merevisi kurikulum yang telah ada secara total, namun dapat dilaksanakan dengan melengkapi kurikulum yang telah ada dengan bidang studi kewirausahaan. Kemudian Soemanto (I989: I46) juga menambahkan dalam pengembangan pendidikan kewirausahaan hendaknya mempertimbangkan hal-hal sebagai berikut:

I) Tidak terlalu banyak merubah sistem pengajaran yang telah berjalan.

2) Disajikan mengikuti pola pengajaran pada bidang studi yang sudah ada.

3) Isi dan ruang lingkup dalam pelaksanaan bidang studi kewirausahaan diusahakan sedemikian rupa sehingga sesuai dengan tingkat-tingkat pendidikan, misalnya titik berat isi bidang studi untuk tingkat sekolah dasar tentunya dibedakan dengan titik berat isi bidang studi kewirausahaan untuk tingkat pendidikan menengah.

4) Dalam kurikulum kewirausahaan hendaknya disesuaikan dengan tingkat-tingkat perkembangan pribadi serta kebutuhan siswa

b. Memberikan Pendidikan dan Pelatihan Kewirausahaan yang Berkesinambungan bagi Tenaga Pendidik

I) Memastikan sosialisasi pentingnya membangun kewirausahaan. Hal ini untuk memberikan rangsangan awal bagi setiap tenaga pendidik tentang pentingnya pembelajaran berbasis kewirausahaan.

2) Bimbingan atasan, teman sejawat mengenai kewirausahaan. Mendapatkan pendampingan dari lingkungan sekolah maupun instansi lain secara kontinyu.

3) Memberikan kempatan mengikuti kegiatan seminar, workshop, pelatihan kewirausahaan. Hal ini akan memperkaya wawasan tenaga pendidik untuk lebih kreatif dalam penyampaian materi kepada siswa.

4) Melakukan studi banding. Studi banding dapat dilakukan pada sekolah-sekolah yang telah menerapkan pembelajaran berbasis kewirausahaan maupun pada jenjang pendidikan yang lebih tinggi.

5) Aktif mengikuti penelitian berbasis kewirausahaan. Merupakan salah satu sarana untuk mengembangkan diri bagi tenaga pendidik. 


\section{c. Penghargaan}

Sama halnya seperti tenaga terdidik, maka bagi tenaga pendidik juga dapat dilakukan pemberian penghargaan, salah satunya seperti kesempatan untuk pengembangan diri. Hal ini juga akan merangsang kreativitas tenaga pendidik untuk lebih aktif dan kreatif dalam kegiatan belajar mengajar.

Efek Penerapan Strategi Manajemen Sekolah Dasar dalam Menumbuhkan Jiwa Kewirausahaan.

Rachmadyanti (2016: 430) menyebutkan pakar kepribadian dan Presiden Direktur Lembaga Pendidikan Duta Bangsa Mien Rachman Uno dalam Wijatno (2009: I25) menyebutkan bahwa untuk menjadi wirausahawan handal, dibutuhkan karakter seperti kemampuan untuk dapat berkomunikasi, mampu membawa diri di berbagai lingkungan, menghargai waktu (time orientation), empati, mau berbagi dengan orang lain, mampu mengatasi stress, dapat mengendalikan emosi, dan mampu membuat keputusan. Mendidik anak menjadi seorang wirausahawan tidak dalam hitungan satu, dua, dan tiga bulan saja, melainkan harus menjadi sebuah proses yang panjang dan sistematis. Berdasarkan berbagai faktor yang mempengaruhi minat anak berwirausaha tersebut, maka sekolah sebagai lembaga formal wajib membimbing siswa, mengarahkan, dan menanamkan pendidikan kewirausahaan sejak dini. Melalui pembelajaran sehari hari, guru dapat memahami karakter anak, minat anak, dan potensi anak. Jika mereka memiliki keinginan untuk berwirausaha kelak, maka sebagai guru harus memotivasi citacita mereka tesebut. Tidak bisa dipungkiri, mungkin tidak semua siswa senang berwirausaha, namun paling tidak sekolah memberikan fasilitas dan bimbingan guna menyalurkan nilai- nilai kebaikan dari memiliki jiwa entreprenurship. Karakter-karakter wirausaha yang dapat ditanamkan kepada siswa sekolah dasar dapat dimulai dari karakter- karakter baik, seperti, kreatif, mandiri, leadership, mampu memecahkann masalah, tidak mudah putus asa, mampu mengelola uang, dan dapat berinteraksi dengan orang lain. Berpikir dan bertindak kreatif adalah suatu upaya untuk menggunakan otak kanan secara aktif.

Poin penting dari keberhasilan manajemen sekolah dalam menerapkan strategi untuk menumbuhkan jiwa kewirausahaan di lingkungan sekolah adalah adanya komitmen dan sinergitas dari semua pihak. Manajemen sekolah sebaiknya mempersiapkan dengan matang hal-hal seperti berikut:

I. Komunikasi dan kerjasama dengan pihak orangtua/wali murid mengenai penerapan pendidikan berbasis kewirausahaan.

2. Komunikasi dengan setiap tenaga pendidik untuk menyesuaikan materi pembelajaran yang berbasis kewirausahaan.

3. Komunikasi dengan pegawai/staff sekolah mengenai pembentukan karakter yang diharapkan dari siswa.

4. Memastikan bahwa baik siswa, guru, maupun pegawai/staff di lingkungan sekolah bersamasama mendukung upaya penanaman jiwa kewirausahaan ini.

\section{Kesimpulan}

Komitmen dan sinergitas manajemen sekolah dengan menerapkan strategi yang tepat dapat mempercepat proses menumbuhkan semangat jiwa kewirausahaan melalui pendidikan di lingkungan sekolah. Penerapan strategi tersebut tidak saja menyasar pada siswa Sekolah Dasar (SD) akan tetapi juga guru sebagai tenaga pendidik. Sinergitas orangtua, guru, pegawai/staff serta pengkondisian sekolah sedemikian rupa baik dari fasilitas maupun kebijakannya juga tidak kalah pentingnya dan harus selaras dengan tujuan akhir yang diharapkan yaitu munculnya lulusan-lulusan pelajar yang berkarakter kewirausahaan. 


\section{Referensi}

Budiawan, Noorman. 20II. Skripsi: Model Pendidikan Market Day di SD Alam Ungaran (Studi tentang Penananman Nilai-Nilai Kewirausahaan pada Siswa Sekolah Dasar). Semarang: Unnes.

Fitriyah, Badi'atul. 2014. Skripsi: Peranan Metode Karyawisata (Field- Trip) dalam Meningkatkan Keaktifan Belajar Anak Usia Dini di PAUD Annisa Pekajangan Kedungwuni Pekalongan. Pekalongan: Sekolah Tinggi Agama Islam Negeri ( STAIN) Pekalongan.

Hakim, Dhikrul. 2012. Prosiding Vol I No. 2: Pengembangan Pendidikan Kewirausahaan Berdasarkan NilaiNilai Budaya Untuk Membentuk Daya Saing Dan Karakter Bangsa. Jombang: Unipdu.

Kasmir. 2016. Kewirausahaan. Jakarta: RajaGrafindo Persada.

Ningsih, Puji Rahayu. 2012. Prosiding: Penerapan Metode Pembelajaran Mini Lab Untuk Melatih Dasar Dasar Entrepreneurship Pada Siswa Menengah Pertama. Jombang: Unipdu.

Pakaya, Iwin.2013. Skripsi: Meningkatkan Kemampuan Siswa Menulis Puisi Melalui Metode Karya wisata Di Kelas II SDN 02 Bulango Utara Kabupaten Bone Bolango. Goronntalo: Universitas Negeri Gorontalo.

Rachmadyanti, Putri dan Vicky Dwi Wicaksono, 2016. Prosiding Seminar Nasional Inovasi Pendidikan: Pendidikan Kewirausahaan Bagi Anak Usia Sekolah Dasar. Surabaya: Universitas Negeri Surabaya.

Setyono, Andik. 2014. Teaching Resource (online: www.eprints.dinus.ac.id) Literature Review. Universitas Dian Nuswantoro.

Susilana, Rudi dan Cepi Riyana. 2009. Media Pembelajaran. Bandung: CV Wacana Prima.

http://www.depkop.go.id/content/read/ratio-wirausaha-indonesia-naik-jadi-3I-persen/

http//kbbi.go.id/karyawisata/

http://sdit-tq.miastasikmalaya.com/) 